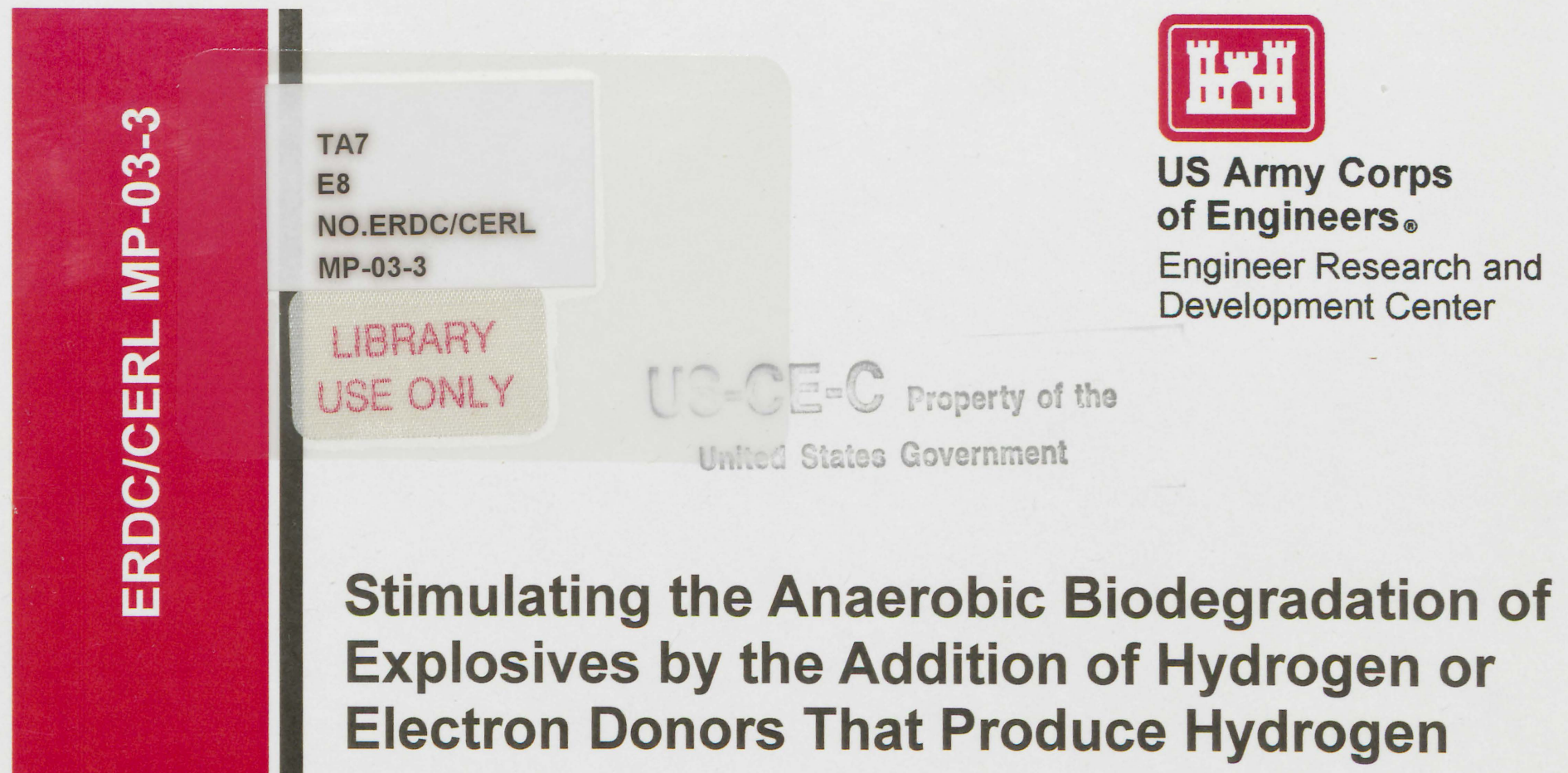

Neal R. Adrian, Clint M. Arnett, and Robert F. Hickey 


$$
53155261
$$

$$
\text { TAT }
$$

\section{Stimulating the Anaerobic Biodegradation of ${ }^{E 8}$ Explosives by the Addition of Hydrogen or Electron Donors That Produce Hydrogen

Neal R. Adrian and Clint M. Arnett

Construction Engineering Research Laboratory

PO Box 9005

Champaign, IL 61826-9005

Robert F. Hickey

The RETEC Group

3900 Collins Road

Lansing, MI 48910

Approved for public release; distribution is unlimited.

Prepared for U.S. Army Corps of Engineers

Washington, DC 20314-1000 

ABSTRACT: The anaerobic biodegradation of hexahydro-1,3,5-trinitro-1,3,5-triazine (RDX), octahydro1,3,5,7-tetranitro-1,3,5,7-tetrazocine (HMX), and 2,4,6-trinitrotoluene (TNT) by a methanogenic mixed culture was investigated. Microcosms containing a basal medium and the mixed culture were amended with ethanol, propylene glycol (PG), butyrate or hydrogen gas as the electron donor and a mixture of TNT $(50 \mu \mathrm{M}), \mathrm{RDX}(25 \mu \mathrm{M})$, and $\mathrm{HMX}(8 \mu \mathrm{M})$. After 29 days, TNT and RDX were completely transformed to unidentified end products in the bottles amended with ethanol, hydrogen, or PG, while $53 \%, 40 \%$, and $22 \%$ of the HMX was transformed, respectively. There was no loss of RDX or HMX in the electron donor unamended control bottles. The ethanol and PG were transformed to near stoichiometric amounts of acetate and propionate, suggesting the immediate electron donor supporting the transformation of the $\mathrm{H}_{2}$ or electron donors that produce $\mathrm{H}_{2}$ may be a useful strategy for enhancing the anaerobic biodegradation of explosives in contaminated groundwater and soils.

DISCLAIMER: The contents of this report are not to be used for advertising, publication, or promotional purposes. Citation of trade names does not constitute an official endorsement or approval of the use of such commercial products. All product names and trademarks cited are the property of their respective owners. The findings of this report are not to be construed as an official Department of the Army position unless so designated by other authorized documents.

DESTROY THIS REPORT WHEN IT IS NO LONGER NEEDED. DO NOT RETURN IT TO THE ORIGINATOR. 



\section{Preface}

This paper was first published by Elsevier Science Ltd. in the Journal of Water Research. Research was performed for Headquarters, U.S. Army Corps of Engineers under 611102AH68, "Processes in Pollution Abatement Technologies" basic research.

The work was performed by the Environmental Processes Branch of the Installations Division (CN), Construction Engineering Research Laboratory (CERL). The CERL Principal Investigator was Neil R. Adrian. This research was supported in part by an appointment at the Research Participation Program administered by the Oak Ridge Institute for Science and Education through a cooperative agreement between the U.S. Department of Energy and CERL and by the Army Research Office through STTR Contract DAAD19-00-C-0112.

CERL is an element of the U.S. Army Engineer Research and Development Center (ERDC), U.S. Army Corps of Engineers. The Commander and Executive Director of ERDC is COL James R. Rowan, EN, and the Director of ERDC is Dr. James R. Houston. 




\title{
Stimulating the anaerobic biodegradation of explosives by the addition of hydrogen or electron donors that produce hydrogen
}

\author{
Neal R. Adrian ${ }^{\mathrm{a}, *}$, Clint M. Arnett ${ }^{\mathrm{a}}$, Robert F. Hickey ${ }^{\mathrm{b}}$ \\ ${ }^{a}$ Army Corps of Engineers, Engineer Research \& Development Center, Construction Engineering Research Laboratory, \\ P.O. Box 9005, Champaign, IL 61821-9005, USA \\ ${ }^{\mathrm{b}}$ The RETEC Group, 3900 Collins Road, Lansing, MI 48910, USA
}

Received 6 August 2002; received in revised form 4 March 2003; accepted 25 March 2003

\begin{abstract}
The anaerobic biodegradation of hexahydro-1,3,5-trinitro-1,3,5-triazine (RDX), octahydro-1,3,5,7-tetranitro-1,3,5,7tetrazocine (HMX), and 2,4,6-trinitrotoluene (TNT) by a methanogenic mixed culture was investigated. Microcosms containing a basal medium and the mixed culture were amended with ethanol, propylene glycol (PG), butyrate or hydrogen gas as the electron donor and a mixture of TNT $(50 \mu \mathrm{M})$, RDX $(25 \mu \mathrm{M})$, and HMX $(8 \mu \mathrm{M})$. After 29 days TNT and RDX were completely transformed to unidentified endproducts in the bottles amended with ethanol, hydrogen, or PG, while $53 \%, 40 \%$, and $22 \%$ of the HMX was transformed, respectively. There was no loss of RDX or HMX in the electron donor unamended control bottles. The ethanol and PG were transformed to near stoichiometric amounts of acetate and propionate, suggesting the immediate electron donor supporting the transformation of the explosives was the $\mathrm{H}_{2}$ evolved during the metabolism of the parent substrate. Our findings suggest that the addition of $\mathrm{H}_{2}$ or electron donors that produce $\mathrm{H}_{2}$ may be a useful strategy for enhancing the anaerobic biodegradation of explosives in contaminated groundwater and soils.
\end{abstract}

Published by Elsevier Science Ltd.

Keywords: RDX; HMX; TNT; Anaerobic; Biodegradation; Explosives

\section{Introduction}

Hexahydro-1,3,5-trinitro-1,3,5-triazine (RDX), octahydro-1,3,5,7-tetranitro-1,3,5,7-tetrazocine (HMX), and 2,4,6-trinitrotoluene (TNT) are secondary high explosives widely used by militaries throughout the world [1]. Wastewater contaminated with these explosives is generated during the production of munitions, as well as from demilitarization operations when excess or outdated munitions are destroyed [2]. In the past, this

\footnotetext{
*Corresponding author. Tel.: + 1-217-373-3483; fax: + 1-217-373-3430.

E-mall address: neal.r.adrian@erdc.usace.army.mil (N.R. Adrian).
}

wastewater was stored in unlined lagoons, often resulting in significant environmental contamination [3]. More than 1200 explosive contaminated sites have been identified within the United States [4]. Many of them pose an additional risk due to the potential for leaching of the explosives to underlying groundwater aquifers. The extent of the problem is just beginning to be realized in the Europe. More than 2000 ammunition production and storage sites are likely contaminated with explosives [5].

The anaerobic biodegradation of explosives is well documented [6]. However, most studies have been carried out under poorly defined conditions with respect to the electron donors and acceptors. For example, studies have demonstrated the anaerobic biodegradation 
of RDX in nutrient broth [7], yeast extract medium [8], and municipal sludge [9]. HMX, although more resistant to degradation than RDX, was also biodegraded in a yeast extract medium [8]. TNT was transformed to 2,4,6triaminotoluene (TAT) by Clostridia in Brain Heart Infusion broth $[10,11]$, mixed cultures in anaerobic sludge [12] and by biofilm obtained from an industrial wastewater treatment plant [13]. These studies unequivocally demonstrated the anaerobic biodegradation of explosives, but they were carried out using media that contain undefined amounts of carbohydrates, amino acids, and peptides, or sludge was used, which is even more undefined. This makes it difficult to identify the electron donors supporting the biodegradation activity.

A better understanding of the electron donors involved in the anaerobic biodegradation of explosives may help to develop strategies that stimulate the activity of only the explosive biodegrading bacteria, as opposed to the total heterotrophic anaerobic bacterial community. This would be highly desirable for developing in situ bioremediation approaches for contaminated soil and groundwater where it is important to limit the amount of biomass (and gas) accumulation to reduce the potential for plugging the formation.

The primary objective of this study was to examine the ability of a series of electron donors to stimulate the anaerobic biotransformation of explosives. Here we report the results of our studies demonstrating that the addition of $\mathrm{H}_{2}$ or electron donors that produce $\mathrm{H}_{2}$ stimulate the anaerobic biotransformation of RDX, HMX, and TNT. These studies should be useful for developing more efficient strategies for in situ bioremediation of explosive contaminated soils and groundwater.

\section{Experimental section}

\subsection{Chemicals}

RDX, HMX, and TNT used in this study were obtained from the Holston Army Ammunition Plant and were all greater than $99 \%$ purity. TAT was obtained from Chem Service (Chem Service, West Chester, PN) and was of the highest purity obtainable. MononitrosoRDX (MNX), dinitroso-RDX (DNX), and trinitrosoRDX (TNX) were obtained from SRI International (SRI International, Menlo Park, CA). All other chemicals were of the highest purity obtainable.

\subsection{Explosive-degrading anaerobic mixed culture}

The biodegradation studies were carried out using an explosive-degrading methanogenic mixed culture that originated from the wastewater treatment plant at the Holston Army Ammunition Plant in Kingsport, TN.
The plant receives wastewater generated during the manufacture of RDX and HMX. The culture degrades RDX when ethanol is added as the sole electron donor [14]. In the absence of RDX, ethanol is completely mineralized to $\mathrm{CH}_{4}$ and $\mathrm{CO}_{2}$, but in the presence of RDX, stoichiometric amounts of acetate accumulate.

\subsection{Explosive biotransformation with various electron donors}

Electron donors were evaluated for their ability to support the anaerobic biodegradation of explosives by comparing TNT, RDX, and HMX disappearance in serum bottles $(160 \mathrm{ml})$ to those in sterile and electron donor unamended controls. The studies were designed to evaluate the biotransformation of the explosives and not the amount of mineralization that may have occurred. The studies were carried out as previously described except as noted below [14]. Serum bottles were prepared by filter sterilizing $(0.2 \mu \mathrm{m})$ a basal salts medium containing $50 \mu \mathrm{M}$ TNT, $25 \mu \mathrm{M}$ RDX, and $8 \mu \mathrm{M}$ HMX. The mineral medium consisted of the following per liter: $\mathrm{NaCl}, 0.8 \mathrm{~g} ; \mathrm{NH}_{4} \mathrm{Cl}, 1.0 \mathrm{~g} ; \mathrm{KCl}, 0.1 \mathrm{~g}$; $\mathrm{MgSO}_{4} \cdot 7 \mathrm{H}_{2} \mathrm{O}, 0.02 \mathrm{~g} ; \mathrm{KH}_{2} \mathrm{PO}_{4}, 1.35 ; \mathrm{K}_{2} \mathrm{HPO}_{4}, 1.75 \mathrm{~g}$; $\mathrm{NaHCO}_{3}, 1.5 \mathrm{~g}$; TES buffer, $4.6 \mathrm{~g}$; resazurin, $0.001 \mathrm{~g}$; trace metal solution, $10 \mathrm{ml}$; and vitamins, $10 \mathrm{ml}$. The $\mathrm{pH}$ of the medium was adjusted to 7.2. Approximately $80 \mathrm{ml}$ of the media was dispensed into sterilized $160 \mathrm{ml}$ serum bottles and sealed with sterile butyl rubber stoppers and aluminum crimp seals. The headspace gas was exchanged with $80 \% \mathrm{~N}_{2}: 20 \% \mathrm{CO}_{2} 3 \times$ and then pressurized to 1.3 ATM. Sterile cysteine-sulfide was added (1 $\mathrm{mM}$ final concentration), followed by $20 \mathrm{ml}$ of the mixed culture. Sterile controls were prepared by adding $20 \mathrm{ml}$ of a steam-sterilized culture and $\mathrm{HgCl}_{2}(0.6 \mathrm{mM}$ final concentration). Filter sterilized $(0.2 \mu \mathrm{m})$ stock solutions of ethanol, propylene glycol (PG) or butyrate were used to amend the serum bottles to a final concentration of $10 \mathrm{mM}$. Bottles containing hydrogen as the sole electron donor were pressurized to $1.7 \mathrm{~atm}$ with a mixture of $80 \% \mathrm{H}_{2}: 20 \% \mathrm{CO}_{2}$. The total volume of the microcosms was $100 \mathrm{ml}$. The study was done in triplicate and bottles incubated statically in the dark at $28^{\circ} \mathrm{C}$.

\subsection{Sampling}

Liquid samples were taken periodically from the serum bottles using a syringe and needle. Samples analyzed for explosives were mixed with acetonitrile (1:1) and filtered through a $0.45 \mu \mathrm{m}$ nylon filter. TAT and ethanol were analyzed the same day samples were taken, while the remaining samples were stored at $-20^{\circ} \mathrm{C}$ until use. Prior to analysis, stored samples were thawed and centrifuged at $12,000 \times g$ for $5 \mathrm{~min}$ in a bench top microcentrifuge. 
Samples of the headspace gases were taken by syringe and needle and analyzed for $\mathrm{CH}_{4}$ and $\mathrm{H}_{2}$ by direct injection into gas chromatographs.

\subsection{Analytical methods}

TAT was analyzed by reverse phase high-pressure liquid chromatography (HPLC) as previously described [13]. RDX, MNX, DNX, TNX, HMX, TNT, 2-amino-4,6-dinitrotoluene (2A46DNT), 4-amino-2, 6-dinitrotoluene (4A26DNT), 2,4-diamino-6-nitrotoluene (24DA6NT), and 2,6-diamino-4-nitrotoluene (26DA4NT) were analyzed by HPLC. The following conditions were used: mobile phase, $65 \%$ water: $35 \%$ acetonitrile; injection volume, $20 \mu \mathrm{l}$; flow rate, $0.8 \mathrm{ml} \mathrm{min}^{-1}$; detector wavelength, $220 \mathrm{~nm}$; column, Waters Symmetry C-8 reverse phase column $(150 \mathrm{~mm} \times$ $3.9 \mathrm{~mm}, 5 \mu \mathrm{m}$ particles) with a guard column of the same matrix. Acetate, butyrate, and propionate concentrations were determined by HPLC using an Alltech anion exclusion column $(300 \mathrm{~mm} \times 7.8 \mathrm{~mm})$ and an UV absorbance detector. The following conditions were used: mobile phase, $0.003 \mathrm{~N} \mathrm{H}_{2} \mathrm{SO}_{4}$; wavelength, $210 \mathrm{~nm}$; injection volume, $20 \mu \mathrm{l}$.

$\mathrm{CH}_{4}$ was analyzed by $\mathrm{GC}$ [13] and hydrogen concentrations were determined using a Trace Analytical RGA3 Reductive Gas Analyzer GC as previously described [15]. Ethanol was analyzed by gas chromatography using a Supelco 60/80 Carbopack B, 5\% Carbowax $20 \mathrm{M}$ packed column $(1.8 \mathrm{~m} \times 2 \mathrm{~mm})$. One $\mu \mathrm{l}$ liquid samples were injected onto the column using an autosampler. The following $\mathrm{GC}$ conditions were used: carrier gas, He; flow rate, $30 \mathrm{ml} \mathrm{min}^{-1}$; injector temperature, $90^{\circ} \mathrm{C}$; detector temperature, $250^{\circ} \mathrm{C}$. The initial oven temperature was $50^{\circ} \mathrm{C}$. This temperature was maintained for $3.5 \mathrm{~min}$, then ramped to $160^{\circ} \mathrm{C}$ at $100^{\circ} \mathrm{Cmin}^{-1}$ and held for $1 \mathrm{~min}$ before returning to $50^{\circ} \mathrm{C}$.
PG was analyzed using a Hewlett-Packard 5890 Series II GC (Hewlett-Packard, Wilmington, DE) equipped with a Hewlett-Packard 7673 autosampler and a Hewlett-Packard 5970 B MSD mass spectrometer. The GC was outfitted with a Supelco VOCOL capillary column $(60 \mathrm{~m} \times 0.25 \mathrm{~mm} \times 1.5 \mu \mathrm{m})$. 1,3-propanediol was used as an internal standard. Samples were mixed 1:1 with methanol containing the internal standard $\left(4 \mathrm{mg} \mathrm{ml}^{-1}\right)$ and filtered $(0.2 \mu \mathrm{m})$. One $\mu \mathrm{l}$ sample volumes were injected into the $G C$ using the following conditions: carrier gas, He; flow rate, $30 \mathrm{ml} \mathrm{min}{ }^{1}$, split flow; injector temperature, $300^{\circ} \mathrm{C}$. The initial oven temperature was $75^{\circ} \mathrm{C}$, which was held for $1 \mathrm{~min}$ and then increased to $205^{\circ} \mathrm{C}$ at $10^{\circ} \mathrm{C} \mathrm{min}^{-1}$. Concentrations of PG and 1,3-propanediol were measured by select ion monitoring at $\mathrm{m} / \mathrm{z} 45$ and 58 , respectively.

\section{Results}

\subsection{Biotransformation of explosives}

The addition of $\mathrm{H}_{2}$, ethanol, or PG to the bottles enhanced the transformation of the explosives by the mixed culture (Table 1). In these bottles TNT was completely depleted and we observed the transient formation of $2 \mathrm{~A} 46 \mathrm{DNT}, 4 \mathrm{~A} 26 \mathrm{DNT}, 24 \mathrm{DA} 6 \mathrm{NT}$ and TAT. More than $50 \%$ of the initial TNT was observed as TAT before the latter compound was transformed to unidentified products. Presumably, the TAT was further transformed to a mixture of azo derivatives [12] and/or phenolic and acetyl derivatives [16]. TNT is reactive and readily transformed by nonspecific reductases and low molecular weight redox mediators [17]. Therefore, we were not surprised to observe the complete loss of TNT and the accumulation of partially reduced intermediates in the controls and in the bottles amended with butyrate, which was not metabolized (see below). 2A46DNT,

Table 1

Influence of ethanol, hydrogen, propylene glycol, and butyrate on explosives removal in incubations containing the methanogenic mixed culture

\begin{tabular}{llcll}
\hline Electron donor & \multicolumn{2}{l}{ Explosive removal (\%) } & \multirow{2}{*}{ TNT reduction products observed } \\
\cline { 2 - 4 } & TNT & RDX & HMX & \\
\hline Ethanol & 100 & 100 & 53 & 2A46DNT, 4A26DNT, 24DA6NT, TAT \\
Hydrogen & 100 & 100 & 40 & 2A46DNT, 4A26DNT, 24DA6NT, TAT \\
Propylene glycol & 100 & 100 & 22 & 2A46DNT, 4A26DNT, 24DA6NT, 26DA4NT, TAT \\
Butyrate & 100 & 0 & 0 & 2A46DNT, 4A26DNT, 24DA6NT, 26DA4NT \\
Unamended & 100 & 0 & 0 & 2A46DNT, 4A26DNT, 24DA6NT, 26DA4NT \\
\hline
\end{tabular}

TNT reduction products formed in butyrate amended and electron donor unamended bottles were persistent. In all other incubations they were only observed as transient intermediates. Explosive removal calculated after 29 days incubation. Electron donors added to final concentration of $6 \mathrm{mM}$. Abbreviations: 2A46DNT, 2-amino-4,6-dinitrotoluene; 4A26DNT, 4-amino-2,6-dinitrotoluene; 24DA6NT, 2,4-diamino-6-nitrotoluene; 26DA4NT, 2,6-diamino-4-nitrotoluene; TAT, 2,4,6-triaminotoluene. 
Table 2

Explosive degradation rates in bottles amended with ethanol, $\mathrm{H}_{2}$, propylene glycol, or butyrate

\begin{tabular}{llll}
\hline Electron donor & \multicolumn{3}{l}{ Degradation rate $\left(\mu \mathrm{Mday}^{-1}\right)$} \\
\cline { 2 - 4 } & TNT & RDX & HMX \\
\hline Ethanol & $>50.0$ & 5.70 & 0.25 \\
Hydrogen & $>50.0$ & 2.95 & 0.39 \\
Propylene Glycol & $>50.0$ & 2.70 & 0.25 \\
Butyrate & $>50.0$ & 0.00 & 0.00 \\
Unamended & $>50.0$ & 0.00 & 0.00 \\
\hline
\end{tabular}

Degradation rate is the maximum observed rate. TNT, RDX, and HMX were added to starting concentrations of 50,25 , and $8 \mu \mathrm{M}$, respectively.

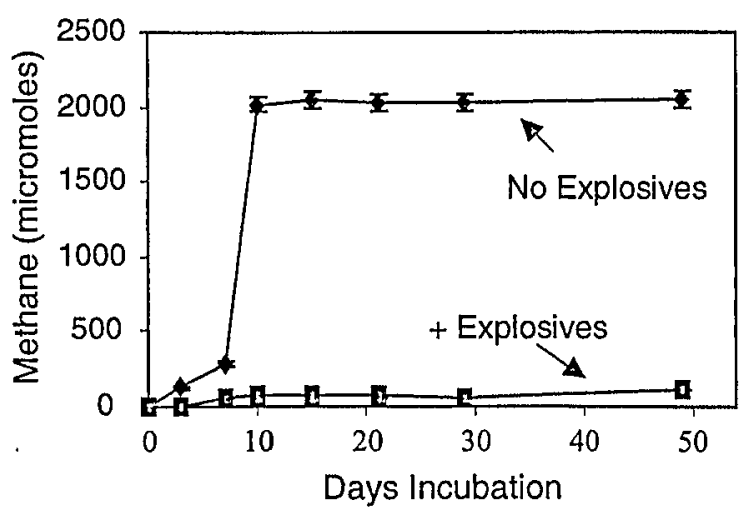

Fig. 1. Effect of explosives on methane formation by a mixed culture. The bottles amended with explosives contained a mixture of $50 \mu \mathrm{M}$ TNT, $25 \mu \mathrm{M}$ RDX, and $8 \mu \mathrm{M}$ HMX. Ethanol was added to an initial concentration of $14 \mathrm{mM}$. Values are the means of three replicates \pm standard deviations. Error bars are not shown for standard deviations that are less than $10 \%$ of the value of the point.

4A26DNT, 24DA6NT and 26DA4NT accumulated and at the end of the study they accounted for $\sim 80 \%$ of the initial TNT added (Table 1). Furthermore, we did not observe the formation of TAT in these incubations, highlighting the requirement of a suitable electron donor to completely transform TNT to TAT.

Ethanol, $\mathrm{H}_{2}$ and $\mathrm{PG}$ also supported the biotransformation of RDX (Table 1). We observed the transient formation of $<5 \mu \mathrm{M} \mathrm{MNX}$ and DNX (data not shown). We did not observe TNX or hydroxylaminodinitrosoRDX, compounds previously observed with this culture [14]. Presumably the ring was destabilized, resulting in the formation of small molecular weight compounds that were further metabolized by the mixed culture $[7,9]$. There was no loss of RDX in the butyrate amended bottles, indicating the stability of the RDX ring under anaerobic conditions in the absence of a suitable electron donor.

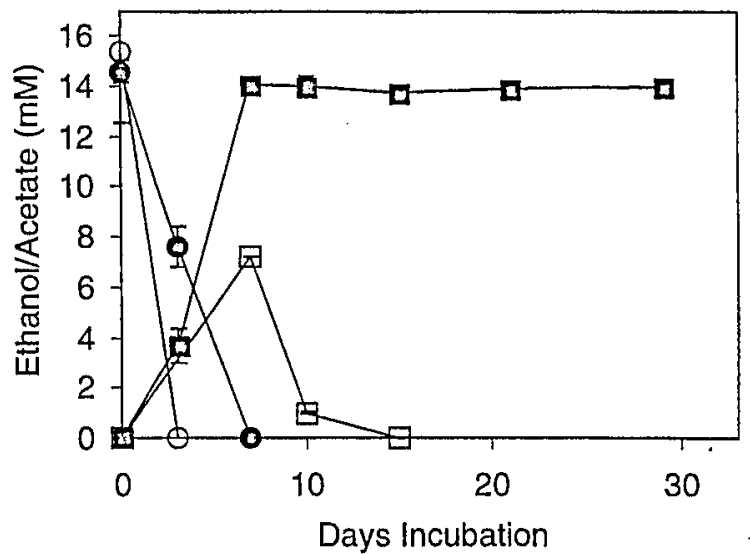

Fig. 2. Effect of explosives on acetate formation in bottles containing ethanol. Bottles amended with explosives contained a mixture of $50 \mu \mathrm{M}$ TNT, $25 \mu \mathrm{M}$ RDX, and $8 \mu \mathrm{M} \mathrm{HMX}$. Ethanol added to a final concentration of $14 \mathrm{mM}$. Symbols: $O$, ethanol (no explosives); 0 , ethanol (+explosives); $\square$, acetate (no explosives); $\mathbf{\square}$, acetate ( + explosives). Values are the means of three replicates \pm standard deviations. Error bars are not shown for standard deviations that are less than $10 \%$ of the value of the point.

HMX was partially degraded in the bottles amended with ethanol, $\mathrm{H}_{2}$, or PG (Table 1). The fate of $\mathrm{HMX}$ was unknown, but two peaks were observed in HPLC chromatograms with shorter retention times. These could not be attributed to any TNT or RDX reduction products; therefore they may have been HMX transformation products, possibly nitroso-HMX intermediates.

The maximum observed biodegradation rates for the explosives are shown in Table 2. TNT was the most rapidly degraded explosive $\left(>50.0 \mu \mathrm{Mday}^{-1}\right)$, followed by RDX and HMX, regardless of which electron donor was added to the serum bottles (Table 2). TNT and RDX were degraded without a lag, while for HMX there was no loss during the first 10 days of incubation in any of the bottles with any of the electron donors.

\subsection{Mass balance}

The presence of the explosives consistently inhibited the formation of methane by the mixed culture. This is most clearly demonstrated in the bottles amended with ethanol (Fig. 1). The presence of the explosives was also a determining factor in whether or not the acetate formed during the metabolism of ethanol was depleted (Fig. 2). In the bottles amended with ethanol but no explosives, acetate was only observed as a transient intermediate, while it accumulated to stoichiometric amounts in the bottles containing the explosives (Fig. 2). 
Table 3

Mass balance of substrate and products in methanogenic mixed culture after 49 days incubation

\begin{tabular}{|c|c|c|c|c|c|c|}
\hline \multirow[t]{3}{*}{ Treatment } & \multicolumn{6}{|l|}{ Available hydrogen (1) } \\
\hline & \multirow[t]{2}{*}{ Generated from oxidation of substrate } & \multicolumn{3}{|c|}{ Recovered in products } & \multirow[t]{2}{*}{ Total recov ${ }^{a}$} & \multirow[t]{2}{*}{$\%$ Recov $^{\mathrm{b}}$} \\
\hline & & Methane & Acetate & Propionate & & \\
\hline Eth & $15.01 \pm 1.17$ & $12.50 \pm 0.37$ & $0.45 \pm 0.00$ & 0 & $12.95 \pm 0.40$ & $86 \pm 8$ \\
\hline Eth $+\exp$ & $16.34 \pm 0.53$ & $0.85 \pm 0.02$ & $10.93 \pm 0.09$ & 0 & $11.78 \pm 0.11$ & $72 \pm 2$ \\
\hline $\mathrm{PG}$ & $16.21 \pm 0.88$ & $0.22 \pm 0.01$ & $0.01 \pm 0.00$ & $13.97 \pm 0.30$ & $14.20 \pm 0.30$ & $88 \pm 3$ \\
\hline$P G+\exp$ & $16.21 \pm 0.88$ & $0.27 \pm 0.26$ & $0.24 \pm 0.08$ & $12.75 \pm 0.96$ & $13.26 \pm 1.18$ & $82 \pm 4$ \\
\hline
\end{tabular}

The explosive amended bottles contained a mixture of TNT, RDX, and HMX at starting concentrations of 50,25 , and $8 \mu \mathrm{M}$, respectively. Ethanol and propylene glycol added to initial concentrations of 14 and $11 \mathrm{mM}$, respectively. Units are available hydrogen $1^{-1}$. Exp $=$ explosives, $E t h=$ ethanol, $P G=$ propylene glycol, Recov $=$ recovered. Values are the means of three replicates \pm standard deviations.

${ }^{a}$ Total hydrogen available in methane, acetate, and propionate.

$\mathrm{b} \%$ Recovery $=$ (total recovered/generated from oxidation of substrate) $\times 100$.

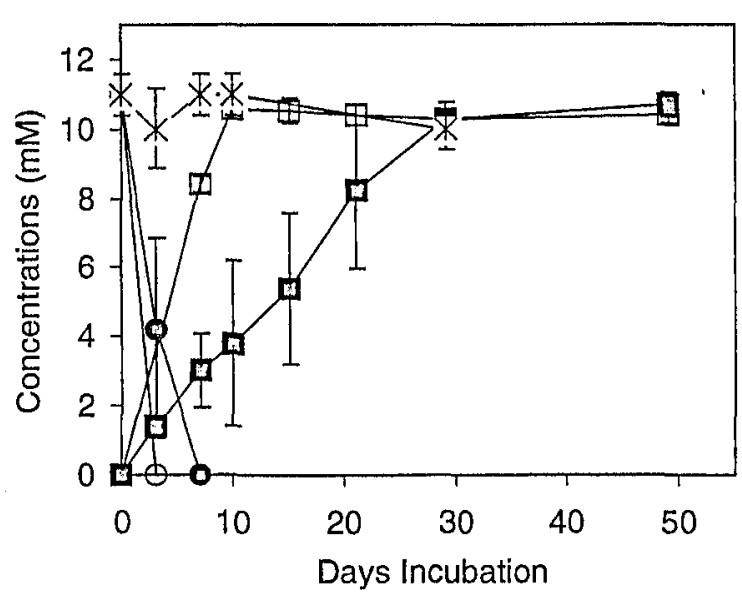

Fig. 3. Endproduct formation in bottles amended with PG. Bottles amended with explosives contained a mixture of $50 \mu \mathrm{M}$ TNT, $25 \mu \mathrm{M}$ RDX, and $8 \mu \mathrm{M}$ HMX. PG added to a final concentration of $10 \mathrm{mM}$. Symbols: $\bigcirc, \mathrm{PG}$ (no explosives); $\boldsymbol{0}$, PG (+explosives); $\square$, propionate (no explosives); $\mathbf{\square}$, propionate (+explosives); *, PG (sterile control). Values are the means of three replicates \pm standard deviations. Error bars are not shown for standard deviations that are less than $10 \%$ of the value of the point.

We recovered $86 \%$ and $72 \%$ of the ethanol as methane and acetate in the bottles amended with ethanol only and ethanol texplosives respectively (Table 3). The ethanol not recovered probably went to biomass formation, reduction of explosives, and an endproduct we observed in the HPLC chromatograms during fatty acid analysis, but were unable to identify. We eliminated butyric acid, formic acid, fumaric acid, propionic acid, isobutyric acid, isovaleric acid, crotonic acid, pentanoic acid, isocaproic acid, caproic acid, heptanoic acid, propanol and isobutanol as likely candidates by comparing their HPLC retention times to the peak of the unknown compound.

$P G$ was rapidiy degraded in both the explosive amended and unamended sample sets (Fig. 3). Propionate was the major end product observed and was not further metabolized. In the former bottles, an additional 22 days was required after the $P G$ was depleted before essentially $100 \%$ of the propionate was observed, while only 8 days in the latter bottles. PG is initially degraded to propanol and propionate via a disproportionation reaction [18]. The propanol formed is subsequently oxidized to propionate. The absence of a stoichiometric formation of propionate from PG before day 29 may reflect the formation of propanol, a compound we did not analyze for. At the conclusion of the study, we recovered $88 \%$ and $82 \%$ of the $P G$ as a mixture of methane, acetate and propionate in the bottles containing PG only and PG + explosives, respectively (Table 3). The $P G$ not recovered probably went to biomass formation and an unidentified peak that had the same retention time as the unidentified peak observed in the ethanol amended bottles discussed above. The compound was observed in the bottles at time zero, but increased in area only in the explosive amended bottles.

The persistence of propionate in the explosive unamended samples indicated the absence of a significant propionate degrading population. Upon extended incubations ( $\sim 6$ months) we did eventually observe the loss of propionate and a corresponding increase in methane, suggesting the mixed culture does harbor a propionate degrading population, albeit a small one. Whether explosives are inhibitory to propionate degradation cannot, therefore, be ascertained from these experiments. 
The inhibition of the heterotrophic methanogens by the explosives or their transformation products was also observed in the bottles amended with hydrogen gas. We were unable to perform an electron balance for the hydrogen amended samples, but the inhibitory nature of the explosives and/or the reduction products on autotrophic methanogenesis was evident. After 29 days incubation, we observed the formation of $250 \mu \mathrm{mol}$ methane in controls, but less than $50 \mu \mathrm{mol}$ in the bottles amended with the explosives, an $80 \%$ decrease. Acetate was a major end product observed in these bottles, indicating the presence of an active homoacetogenic bacterial population (Fig. 4). As was observed in the bottles amended with ethanol, the presence of explosives inhibited the metabolism of acetate that was formed.

There was no loss of butyrate in the explosive amended bottles, even after 50 days of incubation (data not shown). In the control bottles, there was a lag of almost 20 days before any loss of butyrate was observed. After an additional 20 days of incubation, butyrate was completely depleted and no longer detected. The lack of

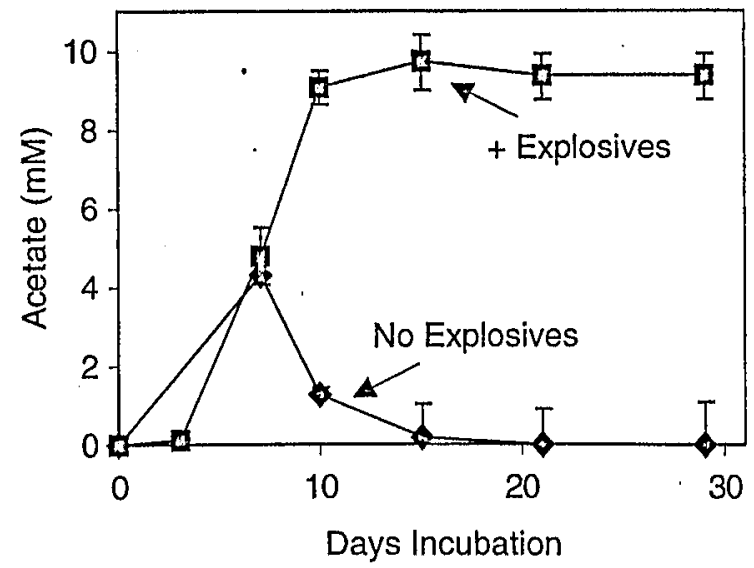

Fig. 4. Acetate formation in bottles containing a high $\mathrm{H}_{2}$ concentration $\left(80 \% \mathrm{H}_{2}, 1.7 \mathrm{~atm}\right)$. Bottles amended with explosives were amended with a mixture of $50 \mu \mathrm{M}$ TNT, $25 \mu \mathrm{M}$ RDX, and $8 \mu \mathrm{M}$ HMX. Values are the means of three replicates \pm standard deviations. Error bars are not shown for standard deviations that are less than $10 \%$ of the value of the point. butyrate metabolism in the explosive amended bottles appears, therefore, to be related to the presence of the explosives.

\subsection{Involvement of $\mathrm{H}_{2}$ in supporting explosives biotransformation}

Hydrogen appears to be the immediate electron donor supporting the anaerobic biodegradation of TNT, RDX, and HMX. This is clearly seen in the bottles amended with $\mathrm{H}_{2}$ as the sole electron donor, but also in the bottles amended with ethanol and propylene glycol (Tables 1 and 2). This is apparent when considering the reaction pathways known for each substrate. The first step in the anaerobic transformation of ethanol is presented in Eq. (1) [19]

$$
\begin{aligned}
& \text { Ethanol }+\mathrm{H}_{2} \mathrm{O} \leftrightarrow \text { acetate }^{-}+\mathrm{H}^{+}+2 \mathrm{H}_{2}, \\
& \Delta G^{0^{\prime}}=+9.6 \mathrm{~kJ} / \text { reaction. }
\end{aligned}
$$

The stoichiometric formation of acetate and the inhibition of methane production suggested hydrogen was accumulating in the explosive amended samples. Previous work with this culture demonstrated that it was unable to utilize acetate as an electron donor for RDX degradation (unpublished data). This supports our contention that syntrophic hydrogen was the immediate electron donor. To see if the hydrogen concentration was greater in the explosive amended bottles, we measured the hydrogen concentration in bottles amended with ethanol and with ethanol and RDX. The hydrogen concentration at the beginning of the study in both sets of bottles ranged between 350 and $365 \mathrm{nM}$ (Table 4). In the explosive unamended bottles, the concentration decreased to $54 \mathrm{nM}$ by day 5 and remained at this level through day 26 . In the RDX amended bottles, however, the $\mathrm{H}_{2}$ concentration increased to $700 \mathrm{nM}$ by day 5 and to $869 \mathrm{nM}$ by day 8 , a more than 16-fold greater concentration than in explosive unamended controls. The stimulation of the RDX biodegradation activity upon the addition of ethanol appears to be due to the buildup of $\mathrm{H}_{2}$ caused by the inhibition of methane production by RDX.

Table 4

Effect of RDX on the hydrogen concentration in the methanogenic mixed culture

\begin{tabular}{llccccc}
\hline Condition & \multicolumn{3}{l}{ Days incubation } & & & \\
\cline { 2 - 7 } & 0 & 5 & 8 & 16 & 21 & 26 \\
\hline Ethanol & $365 \pm 52$ & $54 \pm 1$ & $54 \pm 1$ & $53 \pm 0$ & $53 \pm 1$ & $58 \pm 1$ \\
Ethanol + RDX & $348 \pm 66$ & $700 \pm 10$ & $869 \pm 31$ & $428 \pm 88$ & $82 \pm 9$ & $81 \pm 11$ \\
\hline
\end{tabular}

Ethanol and RDX were added to initial concentrations of $10 \mathrm{mM}$ and $25 \mu \mathrm{M}$, respectively. Values are the means of three replicates \pm standard deviations. 
Hydrogen also appeared to be the immediate electron donor in the bottles that were amended with PG. In the absence of a $\mathrm{H}_{2}$-using methanogen, $\mathrm{PG}$ is metabolized by the $\mathrm{H}_{2}$-producing acetogenic bacteria according to Eq. (2) [18]

propylene glycol $\leftrightarrow$ propionate ${ }^{-}+\mathrm{H}^{+}+\mathrm{H}_{2}$,

$$
\Delta G^{0^{\prime}}=-95.8 \mathrm{~kJ} / \text { reaction. }
$$

The recovery of essentially $100 \%$ of the $\mathrm{PG}$ as propionate and the absence of significant methane formation suggested the hydrogen was also inçreasing and serving as the immediate electron donor stimulating the explosives biodegradation activity.

\section{Discussion}

Most studies demonstrating the anaerobic biodegradation of explosives have been conducted under conditions where the electron donors and acceptors were not well defined. This makes it difficult to determine the immediate electron donor supporting reductive transformation of explosives. Consequently, it is difficult to extrapolate results to the field to devise an appropriate and practical in situ biological treatment strategy for explosive contaminated environments. This prompted us to evaluate the anaerobic biodegradation of explosives under well-defined and rigorously controlled conditions.

Our findings indicate hydrogen is a key factor in stimulating the anaerobic biotransformation of RDX, HMX, and TNT. Others have also suggested the potential involvement of hydrogen in stimulating the anaerobic biodegradation RDX. The addition of hydrogen gas to RDX-contaminated aquifer slurries containing a bicarbonate buffered medium stimulated the anaerobic biodegradation of RDX [20]. Oh et al. observed enhanced RDX degradation in microcosms containing anaerobic sludge and $\mathrm{Fe}^{0}$ filings compared to separate treatments [21]. They concluded that production of cathodic hydrogen was serving as an electron donor for the RDX degrading bacteria. Hydrogen Release Compound ${ }^{\mathrm{M}}\left(\mathrm{HRC}^{\mathrm{M}}\right)$, a polylactate ester that provides a source of $\mathrm{H}_{2}$ upon metabolism of the lactate, has also been shown to support the biodegradation of RDX in an explosives contaminated aquifer [22].

The formation of hydrogen also appears to be a key step in biodegrading TNT by Clostridia. The reduction of the nitro groups has been attributed to the fortuitous activity of the ferredoxin-reducing enzymes when they are growing fermentatively on carbohydrates in a complex medium [23]. During the acidogenic phase of growth, when the activity of the ferredoxin/hydrogenase system is greatest, hydrogen gas is liberated to maintain the redox balance offset by the production of large quantities of partially oxidized fermentation products like alcohols and organic acids [23,24]. The reduction of the nitro groups is more complete and rapid during this time [25]. During the solventogenic stage of growth, when hydrogen formation is minimized, TNT is not completely transformed and the hydroxylamino derivatives accumulate in the growth medium.

Our studies demonstrate syntrophic hydrogen produced during the metabolism of ethanol and $P G$ is also a good source of reducing equivalents for explosives biotransformation. Electron donors that undergo syntrophic oxidations may offer some practical advantages over glucose for delivering reducing power $\left(\mathrm{H}_{2}\right)$ to the explosive biodegrading bacteria in situ. Hydrogen production is maximized and growth yields are small compared to glucose and lactate, important considerations when devising in situ biological treatment strategies where there is the potential for biomass accumulation resulting in plugging at the well screens and/or in the formation itself. The idealized fermentation of glucose to acetate (Eq. (3)) is a highly favorable reaction [19]. The molar growth rate is high, often resulting in the formation of $20-50 \mathrm{~g}$ of biomass per mole of glucose [26]

$$
\begin{gathered}
\text { glucose }+4 \mathrm{H}_{2} \mathrm{O} \leftrightarrow 2 \text { acetate }^{-}+2 \mathrm{HCO}_{3}^{-}+4 \mathrm{H}^{+}+4 \mathrm{H}_{2}, \\
\Delta G^{0^{\prime}}=-206.3 \mathrm{~kJ} / \text { reaction. }
\end{gathered}
$$

The oxidation of ethanol and PG to acetate (Eqs. (1) and (4)) produces two and four moles of hydrogen, respectively. However, significantly less energy is available compared to glucose, decreasing the amount of biomass formed

$$
\begin{aligned}
& \text { propylene glycol }+3 \mathrm{H}_{2} \mathrm{O} \\
& \leftrightarrow \text { acetate }{ }^{-}+4 \mathrm{H}^{+}+\mathrm{HCO}_{3}^{-}+4 \mathrm{H}_{2}, \\
& \Delta G^{0^{\prime}}=-19.2 \mathrm{~kJ} / \text { reaction. }
\end{aligned}
$$

\section{Summary and conclusions}

The ability of reduced electron donors to support explosive biotransformation was the focus of this study. We have shown that $\mathrm{H}_{2}$ or electron donors that produce $\mathrm{H}_{2}$ support the biodegradation of $\mathrm{RDX}, \mathrm{HMX}$, and TNT. Collectively, our evidence supports our contention that inhibition of methanogenesis results in an increase in the hydrogen concentration as the parent electron donor is metabolized. Hydrogen serves, therefore, as the immediate electron donor stimulating the biotransformation of explosives.

PG has several advantages over other substrates for delivering reducing equivalents to the subsurface environment. It is rapidly metabolized and can provide twice the amount of reducing power as ethanol per mole of substrate [18]. Furthermore, $\mathrm{PG}$ is generally regarded as a safe compound (GRAS) and does not have any of the 
safety issues associated with ethanol. However, our studies were inconclusive with respect to propionate, an intermediate produced during the degradation of $P G$, to support the biodegradation of explosives. Further studies are needed to clarify the ability of both propionate and butyrate to supply reducing equivalents for explosives biodegradation. In our study the lack of significant propionate and butyrate degrading populations made it impossible to determine if the presence of explosives inhibited their transformation.

Our studies suggest several strategies can be devised in the field to deliver reducing equivalents in the form of $\mathrm{H}_{2}$ to stimulate the anaerobic biotransformation of explosives. Further research is warranted to determine the stoichiometry of the appropriate reactions and clarify the interrelationships existing between the electron donors, inhibition of methane production, and the subsequent increase in $\mathrm{H}_{2}$. Clarification of whether electron donors affect the explosive catabolic pathways and distribution of end products is also needed. We believe that additional studies will lead to promising new approaches to the in situ biodegradation of explosives.

\section{Acknowledgements}

This research was supported in part by an appointment at the Research Participation Program administered by the Oak Ridge Institute for Science and Education through a cooperative agreement between the US Department of Energy and USACERL and by the Army Research Office through STTR Contract DAAD19-00-C-0112. Although the research described in this article was conducted at the Construction Engineering Research Laboratory for the US Army Engineer Research and Development Center, it has not been subjected to Army review and therefore does not necessarily reflect the views of the Army, and no official endorsement should be inferred.

\section{References}

[1] Gorontzy T, Drzyzga O, Kahl M, Bruns-Nagel D, Breitung $\mathbf{J}$, von Loew E, Blotevogel K-H. Microbial degradation of explosives and related compounds. Crit Rev Microbiol 1994;20:265-84.

[2] Qazi M, Froward B, Schor M, Nelson B. Pink water treatment options. Final Report ADA295802, National Technical Information Service. Springfield, VA, USA, 1995. p.1-99.

[3] Funk S, Roberts D, Crawford D, Crawford R. Initialphase optimization for bioremediation of munition compound-contaminated soils. Appl Environ Microbiol 1993; 59:2171-7.

[4] Scmelling D, Gray K, Kamat P, Schmelling D, Gray K, Kamat $P$. The Influence of solution matrix on the photocatalytic degradation of TNT in $\mathrm{TiO}_{2}$ slurries. Water Res 1997;31:1439-47.

[5] Held T, Draude G, Schmidt F, Brokamp A, Reis K. Enhanced humification as an in-situ bioremediation technique for 2,4,6-trinitrotoluene (TNT) contaminated soils. Environ Technol 1997;18:479-87.

[6] Hawari J, Beaudet S, Halasz A, Thiboutot S, Ampleman. G. Microbial degradation of explosives: biotransformation versus mineralization. Appl Microbiol Biotechnol 2000; 54:605-18.

[7] McCormick N, Cornell J, Kaplan A. Biodegradation of hexahydro-1,3,5-trinitro-1,3,5,-triazine. Appl Environ Microbiol 1981;42:817-23.

[8] Kitts C, Cunningham D, Unkefer P. Isolation of three hexahydro-1,3,5-trinitro-1,3,5-triazine-degrading species of the family Enterobacteriaceae from nitramine explosive-contaminated soil. Appl Environ Microbiol 1994; 60:4608-711.

[9] Hawari J, Halasz A, Sheremata T, Beaudet S, Groom C, Paquet L, Rhofir C, Amplemann G, Thiboutot S. Characterization of metabolites during biodegradation of hexahydro-1,3,5-trinitro-1,3,5-triazine (RDX) with municipal anaerobic sludge. Appl Environ Microbiol 2000; 66:2652-7.

[10] Regan K, Crawford R. Characterization of Clostridium bifermentans, its biotransformation of 2,4,6-trinitrotoluene (TNT) and 1,3,5-triaza-1,3,5-trinitrocyclohexane (RDX). Biotechnol Lett 1994;16:1081-6.

[11] Ederer M, Lewis T, Crawford R. 2,4,6-Trinitrotoluene (TNT) transformed by clostridia isolated from a munitionfed bioreactor: comparison with non-adapted bacteria. J Ind Microbiol Biotechnol 1997;18:82-8.

[12] Hawari J, Halasz A, Paquet L, Zhou E, Spencer B, Ampleman G, Thiboutot S. Characterization of metabolites in the biotransformation of 2,4,6-trinitrotoluene with anaerobic sludge: role of triaminotoluene. Appl Environ Microbiol 1998;64:2200-6.

[13] Hwang $P$, Chow $T$, Adrian N. Transformation of trinitrotoluene to triaminotoluene by mixed cultures incubated under methanogenic conditions. Environ Toxicol Chem 2000;19:836-41.

[14] Adrian $N$, Chow $T$. Identification of hydroxylaminodinitroso-1,3,5-triazine as a transient intermediate formed during the anaerobic biodegradation of hexahydro-1,3,5trinitro-1,3,5-triazine. Environ Toxicol Chem 2001; 20:1874-7.

[15] Mormile M, Gurijala K, Robinson J, McInerney M, Suflita $J$. The importance of hydrogen in landfill fermentations. Appl Environ Microbiol 1996;62:1583-8.

[16] Lewis T, Goszczynski S, Crawford R, Korus R, Admassu W. Products of anaerobic 2,4,6-trinitrotoluene (TNT) transformation by Clostridium bifermentans. Appl Environ Microbiol 1996;62:4669-74.

[17] Cerniglia C, Somerville C. Reductive metabolism of nitroaromatic and nitropolycyclic aromatic hydrocarbons. In: Spain J, editor. Biodegradation of nitroaromatic compounds. New York: Plenum Press; 1995. p. 99-115.

[18] Veltman S, Schoenber T, Switzenbaum M. Alcohol and acid formation during the anaerobic decomposition of propylene glycol under methanogenic conditions. Biodegradation 1998;9:113-8. 
[19] Thauer R, Jungermann K, Decker K. Energy conservation in chemotrophic anaerobic bacteria. Bacteriol Rev 1977; 41:100-80.

[20] Beller HR. Anaerobic biotransformation of RDX (hexahydro-1,3,5-trinitro-1,3,5-triazine) by aquifer bacteria using hydrogen as the sole electron donor. Water Res 2002;36:2533-40

[21] Oh B-T, Just C, Alvarez P. Hexahydro-1,3,5-trinitro-1,3,5triazine mineralization by zerovalent iron and mixed anaerobic cultures. Environ Sci Technol 2001;35:4341-6.

[22] Heaston M, Barnes P, Alvestad K. Reductive biotransformation of nitrate and explosives compounds in groundwater. Proceedings of the Sixth International Symposium on in situ and On-site Bioremediation, San Diego, CA, June 4-7, 2001. Columbus: Battelle Press, 2001. p. 17-24.
[23] Ahmad R, Hughes J. Anaerobic transformation of TNT by clostridium. In: Spain CJ, Hughes JB, Knackmuss H-J, editors. Biodegradation of nitroaromatic compounds and explosives. New York NY: Lewis Publishers Press; 2000. p. $185-212$

[24] Jones D, Woods D. Acetone-butanol fermentation revisited. Microbiol Rev 1986;50:484-524.

[25] Khan 'T, Bhadra R, Hughes J, Anaerobic transformation of 2,4,6-TNT. And related nitroaromatic compounds by Clostridium acetobutylicum. J Ind Microbiol Biotechnol 1997;18:198-203.

[26] Atkinson B, Mavituna F. Biochemical engineering and biotechnology handbook, 2nd ed. New York: Macmillan Publishers Ltd., 1991. p. 132. 
. 
Public reporting burden for this collection of information is estimated to average 1 hour per response, including the time for reviewing instructions, searching existing data sources, gathering and maintaining the data needed, and completing and reviewing this collection of informatton. Send comments regarding this burden estimate or any other aspect of this collection of information, inctuding suggestions for reducing

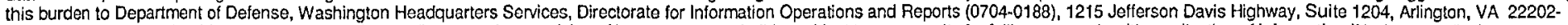

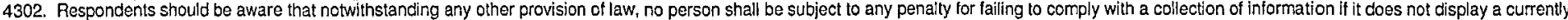
valid OMB control number. PLEASE DO NOT RETURN YOUR FORM TO THE ABOVE ADDRESS.
1. REPORT DATE (DD-MM-YYYY) 09-2003
4. TITLE AND SUBTITLE

\section{REPORT TYPE}
Final

Stimulating the Anaerobic Biodegradation of Explosives by the Addition of Hydrogen or Electron Donors That Produce Hydrogen

6. AUTHOR(S)

Neal R. Adrian, Clint M. Arnett, and Robert F. Hickey
3. DATES COVERED (From - To)

5a. CONTRACT NUMBER

5b. GRANT NUMBER

5c. PROGRAM ELEMENT NUMBER

5d. PROJECT NUMBER

611102 AH68

5e. TASK NUMBER

5f. WORK UNIT NUMBER

8. PERFORMING ORGANIZATION REPORT NUMBER

ERDC/CERL MP-03-3

7. PERFORMING ORGANIZATION NAME(S) AND ADDRESS(ES)
U.S. Army Engineer Research and Development Center (ERDC)

Construction Engineering Research Laboratory (CERL)

PO Box 9005

Champaign, IL 61826-9005

9. SPONSORING / MONITORING AGENCY NAME(S) AND ADDRESS(ES)

U.S. Army Corps of Engineers (USACE)

441. G Street, NW

Washington, DC 20314-1000
10. SPONSOR/MONITOR'S ACRONYM(S)

11. SPONSOR/MONITOR'S REPORT NUMBER(S)

12. DISTRIBUTION / AVAILABILITY STATEMENT

Approved for public release; distribution is unlimited.

\section{SUPPLEMENTARY NOTES}

Copies are available from the National Technical Information Service, 5285 Port Royal Road, Springfield, VA 22161. Direct access: $\mathrm{http}: / / \mathrm{www}$. sciencedirect.com/science?_ob=GatewayURL\&_origin=AUTHORALERT\&_method=citationSearch\&_piikey=S00431354030 02409\&_version $=1 \& \mathrm{md} 5=8 \mathrm{cca} 0801 \mathrm{be} 90 \mathrm{bc} 54 \mathrm{c} 36009130 \mathrm{a} 41345 \mathrm{c}$

\section{ABSTRACT}

The anaerobic biodegradation of hexahydro-1,3,5-trinitro-1,3,5-triazine (RDX), octahydro-1,3,5,7-tetranitro-1,3,5,7-tetrazocine (HMX), and 2,4,6-trinitrotoluene (TNT) by a methanogenic mixed culture was investigated. Microcosms containing a basal medium and the mixed culture were amended with ethanol, propylene glycol (PG), butyrate or hydrogen gas as the electron donor and a mixture of TNT $(50 \mu \mathrm{M})$, RDX $(25 \mu \mathrm{M})$, and HMX $(8 \mu \mathrm{M})$. After 29 days, TNT and RDX were completely transformed to unidentified end products in the bottles amended with ethanol, hydrogen, or PG, while $53 \%, 40 \%$, and $22 \%$ of the HMX was transformed, respectively. There was no loss of RDX or HMX in the electron donor unamended control bottles. The ethanol and PG were transformed to near stoichiometric amounts of acetate and propionate, suggesting the immediate electron donor supporting the transformation of the $\mathrm{H}_{2}$ or electron donors that produce $\mathrm{H}_{2}$ may be a useful strategy for enhancing the anaerobic biodegradation of explosives in contaminated groundwater and soils.

\section{SUBJECT TERMS}

RDX, TNT, biodegradation, HMX, anaerobic, explosives

\begin{tabular}{|c|c|c|c|c|c|}
\hline \multicolumn{3}{|c|}{ 16. SECURITY CLASSIFICATION OF: } & \multirow{2}{*}{$\begin{array}{l}\text { 17. LIMITATION } \\
\text { OF ABSTRACT }\end{array}$} & \multirow{2}{*}{$\begin{array}{l}\text { 18. NUMBER } \\
\text { OF PAGES }\end{array}$} & 19a. NAME OF RESPONSIBLE PERSON \\
\hline $\begin{array}{l}\text { a. REPORT } \\
\text { Unclassified }\end{array}$ & $\begin{array}{l}\text { b. ABSTRACT } \\
\text { Unclassified }\end{array}$ & $\begin{array}{l}\text { c. THIS PAGE } \\
\text { Unclassified }\end{array}$ & & & $\begin{array}{l}\text { 19b. TELEPHONE NUMBER (in- } \\
\text { clude area code) } \\
217-398-5014\end{array}$ \\
\hline
\end{tabular}



